Article

\title{
Populism in Power and Democracy: Democratic Decay and Resilience in the Czech Republic (2013-2020)
}

\author{
Petra Guasti \\ Institute of Sociology of the Czech Academy of Sciences, 11000 Prague, Czech Republic; E-Mail: guasti@soz.uni-frankfurt.de
}

Submitted: 30 June 2020 | Accepted: 6 October 2020 | Published: 17 December 2020

\begin{abstract}
Populism and technocracy reject vertical accountability and horizontal accountability. Populism and technocracy can combine to form 'technocratic populism.' The study assesses the extent to which democratic decay can be traced to the actions of technocratic populists as opposed to institutional factors, civil society, fragmentation and polarization. The main findings of this article are that technocratic populism has illiberal tendencies expressed best in its efforts at executive aggrandizement (cf. Bermeo, 2016). Without an effective bulwark against democratic erosion (cf. Bernhard, 2015), technocratic populism tends to undermine electoral competition (vertical accountability), judiciary independence, legislative oversight (horizontal accountability), and freedom of the press (diagonal accountability). The most effective checks on technocratic populist in power, this study finds, are the courts, free media, and civil society. This article highlights the mechanisms of democratic decay and democratic resilience beyond electoral politics. It indicates that a combination of institutional veto points and civil society agency is necessary to prevent democratic erosion (cf. Weyland, 2020). While active civil society can prevent democratic erosion, it cannot reverse it. Ultimately, the future of liberal democracy depends on the people's willingness to defend it in the streets AND at the ballot box.
\end{abstract}

\section{Keywords}

accountability; Czech Republic; democratic decay; democratic resilience; populism; technocracy; technocratic populism

\section{Issue}

This article is part of the issue "Varieties of Technocratic Populism around the World" edited by Petra Guasti (Institute of Sociology of the Czech Academy of Sciences, Czech Republic) and Lenka Buštíková (Institute of Sociology of the Czech Academy of Sciences, Czech Republic / Arizona State University, USA).

(C) 2020 by the author; licensee Cogitatio (Lisbon, Portugal). This article is licensed under a Creative Commons Attribution 4.0 International License (CC BY).

\section{Introduction}

Populism and technocracy have emerged as two important critiques of representative democracy (Caramani, 2017; Urbinati, 2014). Populism pledges to reinstall the (previously excluded) people at the center of democracy by restoring responsiveness (Kaltwasser, 2014). Technocracy promises to rescue democracy with knowledge, competence and effectiveness, producing 'optimal outcomes' and restoring responsibility (Caramani, 2017; Urbinati, 2014). The critical element of technocratic legitimacy is output-it claims its outcomes driven by experts are superior to 'non-experts.' As such, technocracy is plebiscitarian by nature and has profound conflicts with liberal democracy as well as with populism (cf. Urbinati, 2014).
Notwithstanding these tensions, populism and technocracy share a common enemy-representative party politics (Bickerton \& Accetti, 2017; Caramani, 2017)and aim to significantly redefine the notion of democracy. Both rely on a non-pluralist conception of society, the existence of a unified general interest, and an unmediated relationship between the people and the elite. Populism and technocracy therefore reject both vertical accountability-for populism, vertical accountability is 'self-sanctioning'; for technocracy, vertical accountability is 'impossible' -and horizontal accountability, which is seen as a source of 'procedural constraints for the general interests of society' (Caramani, 2017, pp. 60-61).

Given these similarities, populism and technocracy can combine to form 'technocratic populism' (Buštíková \& Guasti, 2019; de la Torre, 2013; Havlík, 2019), the 
theme of this special issue. This study focuses on three aspects of technocratic populism: 1) attempts among populists in power to undermine accountability; 2) their influence on democratic decay; and 3) their failures (when the institutional guardrails and civil society successfully oppose these attempts (cf. Caramani, 2017; Weyland, 2020).

It builds on the literature examining the ambivalent relationship between populism and democracy (Kaltwasser, 2012, 2014; Mudde \& Kaltwasser, 2014; Weyland, 2020), the negative impact of technocracy and populism on accountability (Caramani, 2017) and its deleterious influence on democracy (Ruth, 2018; Ruth-Lovell, Lührmann, \& Grahn, 2019). It advances the literature on how technocratic populism undermines democratic accountability by: 1) distorting the system of checks and balances (horizontal accountability); 2) limiting electoral competition (vertical accountability); and 3) undermining media freedom, and constraining civil society (diagonal accountability; cf. Bernhard, Hicken, Reenock, \& Lindberg, 2020).

Accountability is defined here as a constraint on the use of power (Lindberg, 2013)-conceptually distinct from responsibility, responsiveness, and representation (Lührmann, Marquardt, \& Mechkova, 2017; Mechkova, Lührmann, \& Lindberg, 2019). Using three V-DEM composite indices-horizontal, vertical, and diagonal accountability-and additional qualitative observation, this article highlights the erosion of all three types of accountability over time (from 2013 until 2019).

This study assesses the extent to which democratic decay can be traced to the actions of technocratic populists as opposed to institutional factors (electoral system, bicameralism), civil society (protests), fragmentation and polarization (cf. Weyland, 2020). It provides new insights about the threat of technocratic populism when technocratic populists are in power in a relatively new democracy-the Czech Republic.

Newer democracies have weaker institutional safeguards and civil society resilience to withstand the (potential) democratic decay caused by technocratic populists' attack on accountability (cf. Bernhard, Hicken, Reenock, \& Lindberg, 2015; Weyland, 2020). The main findings indicate that, if left unchecked, technocratic populism undermines electoral competition (vertical accountability), judiciary independence, legislative oversight (horizontal accountability), and freedom of the press (diagonal accountability). Further, the study shows that the most effective check on technocratic populist in power are courts, free media, and civil society, which form an effective bulwark against democratic erosion (cf. Bernhard, 2015; Weyland, 2020).

The study is structured as follows. Section 2 explores technocracy, populism, and technocratic populism as disfigurations of liberal democracy. In Section 3, data and methods are outlined, and the three types of accountability are operationalized. Section 4 examines technocratic populism's effects on three types of accountability and Section 5 emphasizes the erosion of accountability during the Covid-19 pandemic. In conclusion, the article highlights how technocratic populism has undermined democratic accountability and led to democratic decay, but also how courts, independent media, and civil society can be an effective bulwark against democratic decay and a source of democratic resilience (Bernhard, 2020; Weyland, 2020).

\section{Democratic Disfigurations and Democratic Decay}

While two disfigurations are vital for understanding democratic decay-technocracy and populism (Bickerton \& Accetti, 2017; Caramani, 2017; Urbinati, 2014) - these forms of politics have sometimes had an antagonist relationship. This is hardly surprising, since each seeks a profoundly different goal. Populism promises to restore the power of the people. Technocracy seeks to shift power to the experts (Caramani, 2017). For populism, the will of the majority equals the will of the people-monolithic and hegemonic (Laclau, 2005). For technocracy, people are an abstract entity unable to govern, and popular sovereignty can be fulfilled effectively only by impartial experts driven by reason (Rosanvallon, 2011).

At the same time, populism and technocracy share a proceduralist view of democracy (democracy is reduced to a procedure for selecting the leader). They also share several important features: Both reject 'mediated politics' and see themselves as anti-political (Bickerton \& Accetti, 2017; Rosanvallon, 2011; Taggart, 2002). While left- and right-wing populisms both have ideological agendas, the 'marriage' of populism with technocracy regards the 'left/right' dimension of political competition as obsolete (cf. Caramani, 2017, on the opposition of technocratic populism to traditional party democracy). Democratic procedures are mere 'approximations' (Rosanvallon, 2011) and 'formalisms' (Laclau, 2005).

Technocratic populism is more than the sum of the two parts, however. Technocratic populism asks people to place the power into the hands of the populist leader who will run the state competently (Buštíková \& Guasti, 2019). The leader will embody the people and act on their behalf (Laclau, 2005). In a technocratic social contract, the people become spectators of the new political elite-expert technocrats adopting solutions that benefit the 'ordinary people' (Manin, 1997, on audience democracy; cf. Urbinati, 2014, on plebiscitarianism as a form of the populist disfiguration of democracy).

Once technocratic populists attain power, they want the people to believe in their numbers, enjoy their 'normal life,' and let the experts' rule. Here an important caveat, technocratic populism and technocratic rule have a similar root but are not identical (Buštíková \& Guasti, 2019; Pastorella, 2016). Technocratic populism uses the ideology of numbers and the ideology of expert knowledge to appeal directly to the voters using anti-elite, populist rhetoric (Buštíková \& Guasti, 2019). The state is 
seen like a firm, where there is no place for active citizens or civil society between elections. The populist element of technocratic populism weakens checks and balances, especially institutional safeguards (minority protection), facilitates the centralization of power, reduces the diversity of the public forum and transforms political opposition into the enemy of the people (Ruth-Lovell et al., 2019). The technocratic element narrows political competition and eliminates democratic accountability (Caramani, 2017; Urbinati, 2014); the populist element portrays the opposition as the enemy of the (ordinary) people (Mudde \& Kaltwasser, 2018), rather than a legitimate political adversary.

Once in power, and unconstrained by the need for ideological consistency, technocratic populists are free to adopt policies that maintain voter support, for example, by combining inconsistent redistributive and promarket policies (Buštíková \& Baboš, 2020). In the absence of ideology, technocracy provides an alternative legitimation framework-materially-based output legitimacy (Buštíková \& Baboš, 2020). Technocratic governments increase pressure on domestic political actors, weaken partisan ideology-based politics and loosen accountability ties (cf. Pastorella, 2016). Executive aggrandizement, which undermines checks and balances in the name of the people (Bermeo, 2016), is the most common form of democratic decay. Democratic institutions are bypassed, transparency reduced, oversight and deliberation are minimized. The source of decay originates in excluding pluralistic voices from debates along with restrictions on political opponents and peaceful civil society (Bernhard, 2020; Vachudova, 2019).

Finally, the rise of populism and technocracy can also trigger liberal pushback, whose strength determines the degree of democratic resilience in the face of technocratic populism. Four conditions, I suggest, are necessary for democratic resilience-a free press (critically assessing information by the government); independent courts (ensuring mitigation measures and restrictions remain within the constitutional framework), effective parliamentary opposition (performing government oversight), and active civil society (mobilizing citizens to defend democracy; cf. Bernhard, 2020; Weyland, 2020).

\subsection{Democratic Decay in Pandemics}

The Covid-19 pandemic represented an opportunity for the populists in government to consolidate power. During pandemic states of the emergency, core civil rights and civil liberties were suspended. Populist governments instrumentalized the pandemic restrictions to push through policies, laws, regulations, or hold elections to supervisory boards that would-in a non-pandemic context-have resulted in backlash (Guasti, 2020a). Emergency powers also gave populist leaders the ability to bypass checks and balances. As a result, the pandemic seems to have accelerated democratic decay (Guasti, 2020b).
In theory, the resurgence of technocratic expertise during pandemics should fuel support for technocratic populism. The unprecedented health crisis requires expertise-especially epidemiologists and public health officials. These unelected experts gain a significant degree of trust, yet remain largely politically unaccountable for their advice. The source of decay originates in populist leaders' ability to conceal their accountability behind experts and use technocratic expertise to justify their efforts to curb freedoms. The source of resilience is political opposition and civil society's ability to challenge technocratic expertise, demand transparency in the dissemination of facts and data on Covid-19, and to hold politicians accountable for the types of technocratic (usually medical) expertise that they choose to implement.

\subsection{Explaining the Erosion of Accountability}

We expect to find variations in the erosion of accountability caused by technocratic populists, increasing alongside their growing power:

1) As junior partners in $P M$ Sobotka government (2013-2017), the power of technocratic populists to undermine accountability is limited and indirect-it cannot undermine the judiciary but can skew electoral competition.

2) Leading minority PM Babiš government (2018-2019), the power of technocratic populists to undermine accountability, especially the judiciary grows, but can be constrained by the parliament and the civil society.

3) The Covid-19 pandemic (2020) represents a unique opportunity for further deterioration of accountability. Emergency measures strengthen the executive, weaken parliamentary oversight, and suspend certain rights and liberties (Guasti, 2020b). In this case, the technocratic populists are least constrained, and the strength and resilience of the institutional guardrails and civil society are tested the most (cf. Weyland, 2020). Thus, the pandemic strengthens the cumulative effect of previous erosion of accountability.

\section{Concept Operationalization}

Democratic decay is operationalized as the decline in horizontal, vertical, and diagonal accountability, and democratic resilience is measured as the improvement/lack of erosion on one or more accountability types. The change in accountability is measured by three V-DEM indices and their components (V-Dem Institute, Department of Political Science, University of Gothenburg, Sweden):

1) Vertical accountability captures the mechanisms of formal political participation. The conceptual scheme for the V-DEM vertical accountabili- 
ty index consists of two main aspects: electoral accountability and political parties (Lührmann et al., 2017).

2) Horizontal accountability represents the extent to which state institutions can hold the executive branch of the government accountable (Lührmann et al., 2017). Three institutions are essential in this regard: the legislature, the judiciary, and oversight bodies.

3) Diagonal accountability represents the extent to which citizens can hold government accountable outside of formal political participation (elections; Lührmann et al., 2017). V-DEM models this form of accountability as a function of media freedom, civil society characteristics, freedom of expression, and the degree to which citizens are engaged in politics.

The article supplements the V-DEM accountability indices with annual reports for the Sustainable Governance Indicators by the Bertelsmann Foundation (Guasti, Mansfeldová, Myant, \& Bönker, 2014-2020) to explain the causes of democratic decay. Where necessary, data are supplemented by primary and secondary sources. For the Covid-19 analysis, the analysis relies on primary sources (transcripts of parliamentary debates, voting records in parliament, official press releases, court ruling), and on media reporting.

The analysis focuses on the extent to which the erosion of accountability can be traced to the actions of technocratic populists compared to other factors. It covers the increasing power of technocratic populists and their efforts to undermine accountability. The analysis is structured along the three forms of accountability-vertical, horizontal and diagonal. Negative change (erosion of accountability) represents democratic decay, while positive change (strengthening of accountability), and status quo are conceptualized as democratic resiliencethe ability of the institutional guardrails and civil society to withstand the attempts of technocratic populists to erode accountability.

\section{Democratic Accountability in the Czech Republic (2013-2019)}

\subsection{Vertical Accountability}

Vertical accountability focuses on two interrelated mechanisms of political competition: elections and political parties. In the Czech Republic, both the 2013 and 2017 elections were deemed free and fair (Guasti et al., 2019; OSCE, 2017). No cases of vote-buying were reported in the 2013 and 2017 parliamentary elections. Voter registration is straightforward; all adult citizens, including convicted prisoners, can participate in national elections. There is no voting by mail, which restricts the access of Czech citizens residing abroad, who can only vote at a decreasing number of Czech embassies and consulates.
In 2017, voting-counting errors in central Bohemia led to the first recount in the Czech Republic history.

While the electoral procedures themselves are sound, campaign finance was an issue until the introduction of an independent office for the oversight of party and campaign finance in 2016 (OSCE, 2017). The new law requires parties (and presidential candidates) to have transparent accounts subject to monitoring. The law also establishes limits on donations from a single donor. Campaign finance has been under closer scrutiny since 2017, but media access remains an issue. During elections, the Czech electoral law guarantees parties equal access to state radio and television, irrespective of the party's size or past electoral performance. Municipalities also provide space for billboards, and political advertisements are carried in newspapers. However, there are no guarantees of access to private media, nor monitoring of in-kind services (e.g., billboards purchased by a third party). The dailies of the MAFRA media group, owned by Andrej Babiš, have been criticized for their political bias (Jirák \& Köpplová, 2020). In both the 2013 and 2017 campaigns, ANO dominated the campaign advertisement landscape. Unlike other parties, ANO finances are not dependent on membership contributions or state funding. Instead, the party has a single benefactor to whom it owes a significant debt for previous campaigns - the party Chairman, Andrej Babiš (cf. Buštíková \& Guasti, 2019).

Alongside elections, political competition at the heart of vertical accountability also depends on political parties. The Czech party system has been subject to extreme instability and fragmentation. The previously stable party system of the 1990s and early 2000s, when two parties alternated in power (mostly in coalition governments), became increasingly unstable (Guasti, $2020 b)$. Although overall support for the left and the right remained stable over time, the shifts in voter support happened within the two blocks. On the left, ANO gained the majority of Social Democratic voters and part of the Communist electoral base. On the fragmented right, the significant shifts occurred between Civic Democrats and smaller, liberal parties.

The 2013 elections led to a parliament in which $30.5 \%$ of its members represented new political parties. In 2017, this number grew to $64 \%$. Fragmentation doubled between 2010 and 2019-in 2013, seven parties entered parliament; in 2017, it was nine parties. In 2019, the fragmentation within the parliament further increased to 10 parties, as a new splinter party Tricolor (Trikolora), emerged from the Civic Democratic Party. The instability and fragmentation of the Czech party system have made it difficult to form a stable government, to reach a compromise on pressing issues, but also prevented the Hungarian scenario-a constitutional majority fueling democratic breakdown (cf. Guasti, 2020b).

Overall, vertical accountability deteriorated in the Czech Republic between 2013 and 2019, especially between 2013 and 2017 (Figure 1). To a significant degree, it is possible to ascribe this decline to ANO 
3

2

1

0

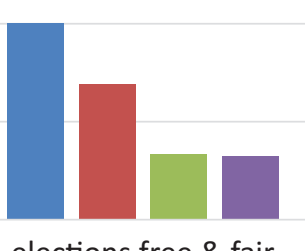

elections free \& fair

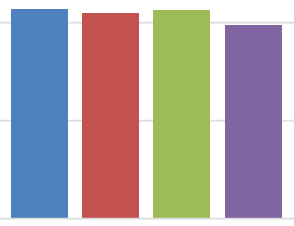

barriers to parties

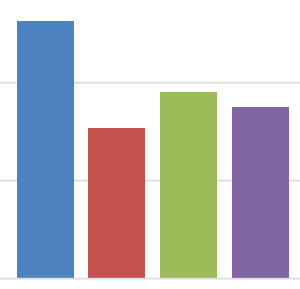

electoral voting irregularities

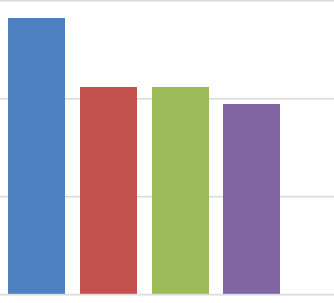

opposition parties autonomy

n $2013 \quad 2017 \quad 2018 \quad$ - 2019

Figure 1. Vertical accountability 2013-2019. Note: Ordinal scale from 0 to 3, the higher the value the higher the quality of measured component. Source: Coppedge et al. (2020).

and Andrej Babiš. In the 2013 elections, Andrej Babiš benefited from unlimited resources, media ownership, and the absence of campaign finance oversight. While the PM Sobotka government amended the law on party finance, the primary source of Babišs power rested in his media ownership. During the government of PM Sobotka, ANO's electoral campaign never stopped (Balík \& Hloušek, 2020). The MAFRA media focused on the successes of ANO ministers and ascribed every misstep to the senior partner (Social Democrats) and the PM (cf. Jirák \& Köpplová, 2020). In fact, in 2017, PM Sobotka left politics and, in 2018, joined the anti-governmental protests (Guasti, 2020a).

\subsection{Horizontal Accountability}

Horizontal accountability focuses on the accountability of the balance of power-the executive branch held accountable by the legislature, the judiciary, and oversight bodies. According to the V-DEM horizontal accountability index, horizontal accountability also eroded between 2013 and 2017, but not between 2018 and 2019 (Figure 2). A closer look indicates the main bulwark is the judiciary-the courts remain independent-and the main weakness is the political opposition. The fragmented opposition struggles to hold the executive accountable and investigate its overreach but has united to prevent executive aggrandizement (cf. Bermeo, 2016).

The Czech Republic is characterized by a weak government and a fragmented opposition (Guasti, 2020b). The relative balance of power between the executive and the legislative branches is because internal divisions have weakened both. Parliamentary oversight is cumbersome, and its dynamics tenuous. The case of Lex Babiš during PM Sobotka tenure exemplifies this. In summer 2016, two of the three governing coalition partners-Social Democrats and Christian Democratsaligned with the parliamentary opposition to amend the law on conflicts of interest. The law sought to prevent media ownership as well as ownership of companies receiving state funding. The bill put a significant wedge between the governing coalition partners, as ANO and its Chairman Andrej Babiš perceived this to be an attempt to stall his rise. Not a single ANO parliamentarian supported the bill, which still received a constitutional majority, and in January 2017, Social Democrats, Christian Democrats, and the parliamentary opposition overruled the presidential veto. The Constitutional Court later upheld the law.

PM Babiš often fails to hide his disdain for parliamentary oversight (and deliberation), which he perceives as impeding governance. PM Babiš's government is more constrained by its lack of parliamentary majori-

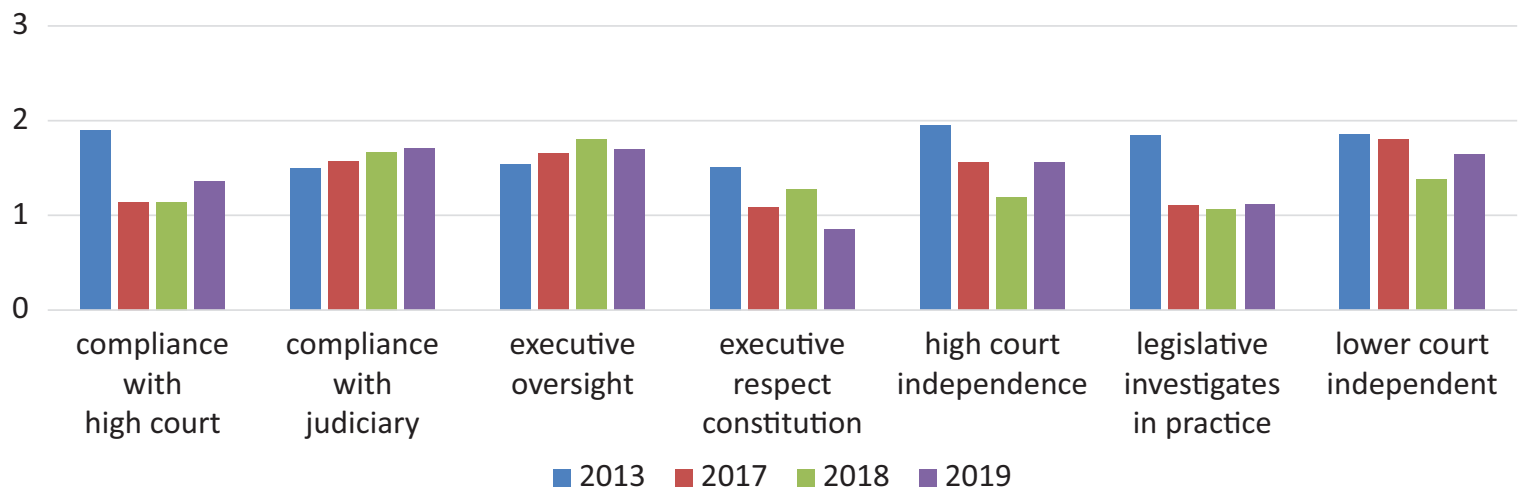

Figure 2. Horizontal accountability 2013-2019. Note: Ordinal scale from 0 to 3, the higher the value the higher the quality of measured component. Source: Coppedge et al. (2020). 
ty and internal divisions (Social democrats are not united in their support for governmental bills) than by effective parliamentary oversight. PM Babiš's minority government often relies on the opposition Communists to support its legislation. The support for each piece of legislation is negotiated individually outside the regular channels (parliamentary committees) and without oversight. Babišs's government has attempted but failed to pass some laws that would benefit the PM because the opposition united against it. This was particularly visible during the Covid-19 pandemic and will be discussed in the next section.

Between 2013 and 2017, the party system and its key players were in turmoil-fragmented, facing new challengers (including the re-emerged radical right and the Pirate party) and unable to effectively oppose the rise of ANO. After the 2017 elections, the opposition remained fragmented, and ANO has undercut its coalition partner (Social democrats) using informal deals with the Communists. Between 2013 and 2020, ANO practically cannibalized the left-side of the political spectrum. Support for ANO remains stable, but both Social Democrats and especially the Communists are now hovering around the $5 \%$ threshold. While fragmentation undermines oversight, it also has a positive effect. In combination with the electoral law, it has prevented ANO from increasing its support above 32\%, thus requiring it to enter into coalition and/or minority governments.

During Sobotka's and Babiš's governments, ANO held the Ministry of Justice. In both, judiciary reforms were proposed and failed. The 2016 reform attempt (by Justice Minister Robert Pelikan) focused mainly on changing the rules on the selection of judges and preventing candidates without trial experience from entering regional courts. The reform was opposed by significant figures within the judiciary who disagreed with the outcome and the process (lack of continuity and lack of consultation with the judicial branch). Based on the strong opposition of the judiciary, tired of ever-changing proposals by every new Minister of Justice (including the current Minister, there were 15 in the period from 1993 to 2016), the reform was postponed indefinitely.

Robert Pelikan was not re-appointed in Babiš's government. Instead, as the fraud and corruption cases facing the PM and his family culminated, Andrej Babiš appointed Marie Benešová as his Minister of Justice. Before her appointment, Benešová was very vocal in her (unfounded) accusation that it is possible to "order police investigations" in the Czech Republic. This was an overt delegitimization of the investigation of the PM. Her appointment raised fears of government overreach and triggered protests. The protests grew even stronger after Benešová denounced the demonstrators as ignorant and capricious children.

In her role, Benešová has clashed with the Prosecutor General, who is in charge of the ongoing investigation into the PM and his family. In 2019, Benešová introduced a new judiciary reform, which would shorten the term of the current Prosecutor General, thus enabling the PM to nominate a 'friendlier' figure. Experts and the judiciary saw the move as political interference and an attempt to curtail the judiciary's independence. Like its 15 predecessors, the reform was dead on arrival-rejected by the judiciary, the public, and the parliament.

The Constitutional Court exercises the most active control over executive actions. It is sometimes described as a 'utility tool for correcting politics' (Pospíšil, 2020). The nomination procedure involving both the President and the Senate ensures balance in judges' political views. The court is fiercely independent, and its judgments have triggered much controversy across the political spectrum (Pospíšil, 2020). While governments clash with the courts, they also predominantly comply (a recent example of a Covid-19 judgment will be discussed in the next section).

In sum, while the erosion of horizontal accountability was an issue during Sobotka's government, it was mainly a result of polarization and fragmentation. An active attempt by the ANO Minister of Justice to curtail PM's investigation failed. Under Babiš government, politically motivated judicial reforms also failed, as did attempts to adopt laws that would resolve PM's legal troubles regarding conflicts of interest. The fragmented opposition is thus capable of uniting to prevent executive aggrandizement (cf. Bermeo, 2016). The courts are independent, and the Constitutional Court acts as a useful corrective (Pospíšil, 2020). Attempts to undermine horizontal accountability and the rule of law have been largely unsuccessful due to a combination of veto points. Furthermore, the attempts by ANO triggered large scale protests (Guasti, 2020a). Both institutional veto points and civil society's agency prevent democratic decay (cf. Weyland, 2020).

\subsection{Diagonal Accountability}

Diagonal accountability focuses on civic participation and media freedom. Media freedom is crucial in enabling citizens to hold politicians accountable (Lührmann et al., 2017; Mechkova et al., 2019). The willingness of citizens to be engaged in public affairs beyond elections acts as an essential check on government action and a bulwark against democratic erosion (Bernhard, 2020). According to the V-DEM diagonal accountability index, there was no significant change in diagonal accountability in the period under study (2013-2019), but a stable decline since 1990 (Guasti, 2016, 2020b; Jirák \& Köpplová, 2020). A closer look at the two types of components-media and civic participation (Figure 3)-suggest the media indicators are in decline, while civic participation criteria are in flux (cf. Guasti, 2016, 2020b).

Czechia has long been characterized by a significant degree of media freedom, partly because of the independence of public media and foreign ownership of private media (cf. Jirák \& Köpplová, 2020). However, the 


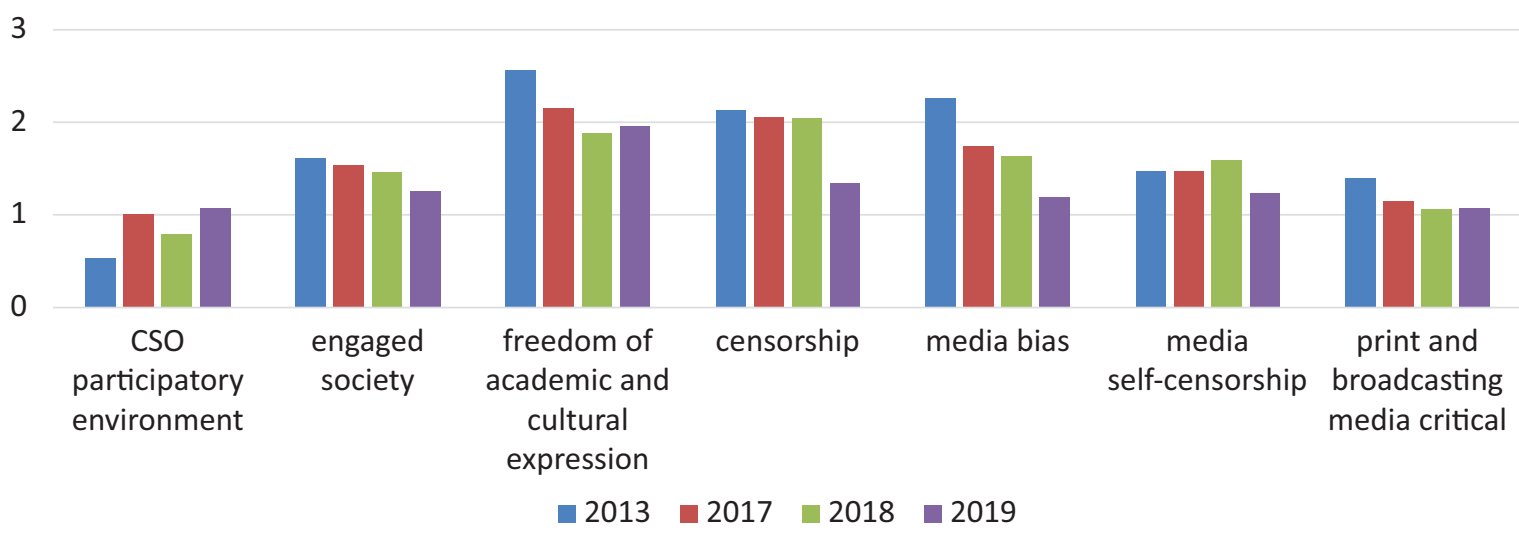

Figure 3. Diagonal accountability 2013-2019. Note: Ordinal scale from 0 to 3 , the higher the value the higher the quality of measured component. Source: Coppedge et al. (2020).

private media market in Czechia has changed significantly in recent years. The most critical change has been the concentration of media ownership, the departure of several foreign media owners, and the broadening of the scope of media holdings (print, online, radio, and television). In recent years, print media readership has declined significantly, while online media has grown (Jirák \& Köpplová, 2020). Projects include crowd-sourced media outlets, some of which eventually venture into print (e.g. Dennik N). The concentration of ownership in the printed media was not as evident in the TV sector until 2019, when an influential investment company PPF owned by Petr Kellner announced its intention to purchase the U.S. owned Central European Media Enterprises (CME) - a block its TV channels in the Czech Republic, Slovakia, Bulgaria, and Romania.

Andrej Babiš's acquisition of MAFRA in 2013 was integral to his rise to power. It not only transformed the Czech media landscape but also profoundly skewed political competition (Chaloupkova, 2020). MAFRA dominates the daily print media, with an estimated 2,4 million readers, and online media, with an estimated 3,4 million daily users (Guasti, 2020b). Andrej Babiš has used his media power to support his political rise and denigrate any alternatives (Buštíková \& Guasti, 2019).

During 2020, information emerged that state-owned companies such as the Czech railways represent a significant advertiser in MAFRA. Furthermore, pandemic state aid for cultural institutions, announced in June 2020, will disproportionally benefit MAFRA. The argument of the government that the aid is being distributed proportionally according to the readership does not hold water, since the second-largest media group will receive significantly smaller aid - absolutely and proportionally (Kottova, 2020).

The V-DEM components identify media bias (in both 2013-2017 and 2018-2019), print and broadcasting media lacking critical reporting (2013-2017), media censorship, and self-censorship (2018-2019) as the main issues undermining media freedom. The Sobotka period was defined by MAFRA media attacking the PM and social democratic ministers, while praising Andrej Babiš and ANO Ministers. Simultaneously, the rise of alternative online media has contributed to a less biased and more critical reporting. However, the fight for freedom of expression has shifted to the fight for the control of public media and direct and indirect state support for MAFRA (pandemic state aid, advertisement by state companies; cf. Bátorfy \& Urbán, 2020 for a detailed look on the transformation of the Hungarian media market via state advertisement).

Moving from media to civic participation beyond elections, I examine three aspects of an 'engaged society' - party membership, civil society, and protests. According to the V-DEM indicators, the Czech Republic's participatory environment remains resilient, although slightly declining under the PM Babiš (2018-2019). Societal engagement slightly declined under PM Sobotka and PM Babiš.

Czech parties have never had a broad membership base (except for the Communist Party, and to the lesser degree Social Democrats). In the last two years, the decline in party membership accelerated. The Communist Party is the largest, with 34,000 members down from over 100,000 in 2004, almost $70 \%$ ). Civic Democrats have lost almost $70 \%$ of their membership since 2009 (now approximately 13,000 members), and a further decline is expected in connection with the new splinter party (the Tricolor-radicalized mainstream right). Christian Democrats lost 35\% members in the last three years (now 22,000 members). Social Democrats have lost more than $30 \%$ of their members in the last three years (now 13,500 members). The new radical right Freedom and Direct Democracy is the only party that has increased in membership, with a total of 4,500 members since its establishment in 2015 (Rovensky, 2019).

Two new parties that are currently present in the Czech parliament have stable but minimal membership bases. ANO has 3,271 members; the Pirates report approximately 1,000 members (Rovensky, 2019). While similar in terms of extremely narrow membership base, ANO and the Pirates have a diametrically different inter- 
nal organization. Pirates have robust internal democratic procedures, while ANO is a party of one man. The billionaire founder Andrej Babiš was reelected chair at the party's congress in February 2017 (95\% of the votes) and has ruled the party the same way he does his companies. Babiš lent the ANO party a large sum of money, and his company Agrofert-in trust-provides ANO accounting and PR services (Buštíková \& Guasti, 2019). In 2017, ANO changed its internal party rules and further strengthened Andrej Babiš by giving him the right to intervene in selecting and ranking party candidates on candidates lists.

Civil society has a long tradition in the Czech Republic and has historically played an essential role in the transition to democracy and keeping governments accountable (Guasti, 2016, 2020a). The 2009 economic crisis acted as a catalyst for citizen engagement in three respects. First, it challenged civil society and trade unions to define their relationship to the state; second, it highlighted the need to communicate with the public and establish active ties between organized civil society and the broader public, and third, it brought civil society closer to private companies-both to ensure financial viability but also to foster engagement (Guasti, 2020a). In recent years number of new NGOs emerged focusing on accountability (Reconstruction of the State, State Watchman; cf. Guasti, 2020b).

Large scale protests marked the period of PM Babiš. The most important initiative that has mobilized crowds of the size unseen since 1989 is A Million Moments for Democracy (MMD). Founded on the anniversary of the Velvet Revolution on November 17, 2017, MMD was launched on Facebook, and called for the Prime Minister to meet his campaign pledge to develop democracy (before the elections, Babiš mailed voters a letter offering a 'new social contract'). When nothing happened, a petition calling for Babiš to resign followed. Since April 2018 , there has been an active protest campaign that includes over 300 cities and villages.

From the onset, MMD and its leaders renounced political ambition and signaled their support for democratic political parties (explicitly rejecting the Communists, radical right, and ANO). This is a doubleedged sword-it allows the MMD to be inclusive and pluralistic, but limits its political impact. In June 2020, the $M M D$, for the first time, met with leaders of five democratic political parties to discuss policy and urging the opposition parties to overcome political fragmentation.

In sum, diagonal accountability has remained stable over the period under study (2013-2019), but is a mixed bag. On the one hand, media freedom is increasingly under attack. Established political parties are losing membership at an accelerating speed, and new parties without members (ANO, Pirates) currently control over $42 \%$ of parliamentary seats. On the other hand, civic engagement is growing, and protests prevented an erosion of horizontal accountability. Andrej Babiš's political strategy relies on convincing people to remain passive, leaving politics to the experts. However, it has failed to curb participation and civil society (cf. Bernhard, 2020; Bernhard et al., 2020).

\section{Democratic Accountability During Covid-19 Pandemic}

The Covid-19 pandemic represents a unique opportunity for the further deterioration of horizontal and diagonal accountability: Emergency measures strengthen the executive, weaken parliamentary oversight (erosion of horizontal accountability), and suspend certain rights and liberties (erosion of diagonal accountability). Under the pandemic state of emergency, technocratic populists were less constrained than they were as junior partners in PM Sobotka government (2013-2017) or while leading PM Babiš minority government (2018-ongoing). The strength and resilience of the institutional guardrails and civil society are being tested (cf. Weyland, 2020).

In the first wave (February to July 2020), the Covid-19 response in the Czech Republic was technocratic-driven by experts adopting swift and aggressive measures, including the closure of borders, a travel ban (citizens not allowed to leave the country), and compulsory masks (Guasti, 2020a). As the critique of the government's initially chaotic (and for some, illiberal) response mounted, the PM backtracked to the standard emergency response enabling the Minister of Interior (junior partner in the government) to lead the emergency response body (Guasti, 2020a). Nevertheless, even then, the acquisition of the personal protection equipment (PPE) for essential personnel continued as a form of political competition between the coalition partners, while failing to satisfy the demand for PPE. The cost of the popularity contest between ANO and Social democrats was a decrease in transparency, a rise in clientelism, and a loss of trust. The backlash against the government's handling of the pandemic grew, but ANO support remained relatively stable, deepening societal polarization. According to some surveys ANO support started to deteriorate during the late summer and especially in September 2020 during the onset of the second wave. However, ANO remains the strongest party (Soukup, 2020).

Parliamentary oversight and investigative journalism were crucial in identifying problems in the government response to Covid-19 (especially the purchase of PPE from companies based in tax havens, rather than domestic producers; the price of PPE). The government initially attempted to instrumentalize the pandemic to push through legislation benefiting the PM (an amendment that would eliminate the PM's conflict of interest by decreasing transparency in company ownership). The media reported on the attempt and explained the amendment's implications. The opposition unified and pushed back against the governmentthreatening not to reauthorize the state of emergency if the government went ahead. The government withdrew the bill. Similarly, when a group of senators publicly announced their intention to bring the travel ban 
to the Constitutional Court for review, the government abandoned the policy.

Perhaps the most significant legal pushback against the government's pandemic measures came from the Prague municipal court. On April 21, 2020, the court ruled that emergency measures, including limits on freedom of movement, the travel ban, and the compulsory closure of large shops, were illegal. The ruling stipulated that the government measures were arbitrary, chaotic, and incomprehensible. The court explicitly highlighted the need to protect both the health of the people and the health of democracy. The government was provided one week to mitigate the situation and legal recourse. After the President and the PM's initial hesitation and attempt to blame the court for endangering public health, the government fully accepted the ruling and amended the situation.

The chaotic Covid-19 response mobilized civil society. In the initial phases of the pandemic, civil society mobilized to produce home-made masks. As the state of emergency ended and the country started to reopen, MMD demanded accountability for the government's Covid-19 response and called for anti-government demonstrations in Prague and across the country for June 9, 2020. The Minister of Health (ANO) accused MMD of undermining the Covid-19 response, called the protests "illegal," and demanded the Police prevent large gatherings (Guasti, 2020a). The Police responded uniquelyreminding the Minister that its role is to protect people's constitutionally enshrined rights to protest. At the same time, it is the responsibility of the public health authorities to protect public health. MMD responded by asking demonstrators to wear masks, respect distance, and use hygienic precautions. The demonstration went ahead and took place in Prague and 166 other municipalities across the country.

In sum, during the first wave of Covid-19 (February to June 2020), the government's technocratic competence was tested, and its increased efforts to undermine horizontal and diagonal accountability failed. During a pandemic, populist rhetoric cannot entirely obscure a lack of competence. Parliamentary opposition exercised oversight by demanding re-authorization of the state of emergency. Even if the Communists vetoed some parliamentary hearings that would shed light on the government's chaotic pandemic response, investigative journalists provided information about gaps and mishaps. Prague's municipal court pushed back against some governmental measures, ensuring that the pandemic response did not undermine democracy and the rule of law. Czech civil society, universities, and startups were able to mitigate the scarcity of PPE effectively and mobilized to defend democracy and the rule of law simultaneously.

\section{Conclusions}

Previous studies have shown how populism in power erodes horizontal accountability in Latin America
(Ruth, 2018), and that diagonal accountability can prevent democratic erosion (Bernhard, 2020; Bernhard et al., 2015, 2020). The main findings of this article are that technocratic populism has illiberal tendencies expressed best in its efforts at executive aggrandizement (cf. Bermeo, 2016). Without an effective bulwark against democratic erosion (cf. Bernhard, 2015; Weyland, 2020), technocratic populism tends to undermine electoral competition (vertical accountability), judiciary independence, legislative oversight (horizontal accountability), and freedom of the press (diagonal accountability). The most effective checks on technocratic populist in power, this study finds, are the courts, free media, and civil society.

This article demonstrates that Andrej Babiš used his political power to weaken his business opponents and exploited his media power to weaken the senior coalition partner (Social Democrats), maintaining support by undermining parties on the left (Social democrats and the Communists), with whom he governs. Over the period under study, all three types of accountability eroded (horizontal accountability only between 2013-2017). However, the erosion of vertical and horizontal accountability resulted from polarization and fragmentation that are conducive to, but not created by, technocratic populism. Only the erosion of diagonal accountability can be ascribed to the technocratic populists (cf. Vachudova, 2019).

Babiš's weaponization of private media led the Social democrats and the opposition to unite and adopt party finance regulations and a new law on conflicts of interest. Still, Babiš continues his attack on diagonal accountability, increasing pressure on state media (attempt at capturing media oversight bodies). At the same time, statecontrolled companies represent the primary source of advertisement revenue for MAFRA. Additional ANO attempts to tamper with the court nomination procedures have thus far failed (horizontal accountability). Erosion of horizontal and diagonal accountability backfired and triggered large scale protests.

During the (first wave of the) Covid-19 pandemic, Babiš's government attempted to use broad emergency powers to aggrandize executive power (cf. Bermeo, 2016), weaken oversight, and ban protests (Guasti, 2020a). These attempts were dressed in the language of technocratic competence and public health. However, the courts and civil society largely withstood the pressure. Public protest rejected the new social contract of passivity and demanded accountability (cf. Bernhard, 2020; Bernhard et al., 2015, 2020). Nevertheless, ANO remains the strongest party (cf. Soukup, 2020). While protests are critical in a representative democracy, elections are still the primary legitimation mechanism (cf. Taggart, 2002). Populists in power have effective tools to maintain voter support, including targeted policies (cf. Buštíková, 2019; Buštíková \& Baboš, 2020).

Covid-19 presented a unique opportunity for technocratic populists in power to the erode horizontal and 
diagonal accountability. Faced with the pandemic, technocratic promises are being tested. Covid-19 outlines the limits of both the technocratic populism and civil society resilience. Opposition, courts, and civil society have been effective at preventing further democratic decay, but the second wave of the pandemic will present new tests.

This article's contribution is three-fold-for the study of populism, democratic backsliding, and polarization. For the study of populism, it outlines the inherent tension between technocratic populism and liberal democracy. For technocratic populism, democracy is a selection procedure for a leader. Technocratic populism, like its left- and right-wing counterparts, opposes the mutual constraints inhibiting absolute power in a democracy (Huber \& Schimpf, 2017, pp. 149-152; cf. Zulianello, 2020 on varieties of populist parties and their system integration). Nevertheless, unlike left- and right-wing populists, which often support majoritarian measures such as referenda (cf. Urbinati, 2014), technocratic populists seek passivity or introduce top down innovations (Castaldo \& Verzichelli, 2020; Perottino \& Guasti, 2020). The people are perceived as capable of selecting the leader, but only the leader and experts can gauge the general will and common interest (Caramani, 2017; cf. Rosanvallon, 2011).

For the democratic backsliding literature, this article highlights the mechanisms of democratic decay and democratic resilience beyond electoral politics (cf. Buštíková \& Guasti, 2017). It indicates that a combination of institutional veto points and civil society agency is necessary to prevent democratic erosion (cf. Weyland, 2020). The legitimacy of technocratic populism is in output, so pandemics test the technocratic promise of competence. When competence fails (to maintain support), technocratic populists have turned to more targeted social policies (cf. Buštíková \& Baboš, 2020).

For the study of polarization, this article shows that under proportional electoral systems, fragmentation can be conducive to maintaining the status quo, for it not only inhibits the opposition from reversing the status quo but also prevents technocratic populists from turning an illiberal swerve into an illiberal turn (cf. Buštíková \& Guasti, 2017). While active civil society can prevent democratic erosion (Bernhard, 2020), it cannot reverse it. Without unified political opposition, civil society can maintain the status quo, but not to bring about change. Ultimately, the future of liberal democracy depends on the people's willingness to defend it in the streets AND at the ballot box. At the moment, two opposing projects polarize the Czech Republic-technocratic populism (Buštíková \& Guasti, 2019; Lorenz \& Formánková, 2020; cf. Manin, 1997) versus liberal democracy with active citizens and civil society.

In times of populism, anti-establishment and antielite delegitimization strategies are critical (Aprasidze \& Siroky, 2020; Buštíková \& Guasti, 2019; Castaldo \& Verzichelli, 2020), and particular attention ought to be paid to the effect of populism in power on democra- cy (Caiani \& Graziano, 2019; Kaltwasser, 2012, 2014). Populists seek to reframe political competition while stifling horizontal, vertical, and especially diagonal accountability (cf. Ruth-Lovell et al., 2019). Future research would benefit from further comparing the effects of populisms (left-, right-, technocratic) in power on accountability, thereby advancing our understanding of the tradeoffs between the positive and negative effects of populism.

\section{Acknowledgments}

The study has been completed with funding from the Strategy AV21 of the Czech Academy of Sciences, research programme No. 15-Global Conflicts and Local Interactions: Cultural and Social Challenges. I would also like to thank participants of the international workshop "Anti-Elitism: Varieties of Technocratic Populism around the World" held at the Friedrich Schiller University in Jena, 10-11 February, 2020, for comments and discussion on the early version of this article. I would like to most warmly thank to Lenka Buštíková, Michael Bernhard and David Siroky for extensive comments on multiple versions of this article; and to the three anonymous reviewers for their comments and recommendations.

\section{Conflict of Interests}

The author declares no conflict of interests.

\section{References}

Aprasidze, D., \& Siroky, D. S. (2020). Technocratic populism in hybrid regimes: Georgia on my mind and in my pocket. Politics and Governance, 8(4), 580-589.

Balík, S., \& Hloušek, V. (2020). Permanent campaigning and pitfalls of proportional representation with fragile parties: Elections and party system in Czechia. In D. Lorenz \& H. Formánková (Eds.), Czech democracy in crisis (pp. 89-110). London: Palgrave Macmillan.

Bátorfy, A., \& Urbán, Á. (2020). State advertising as an instrument of transformation of the media market in Hungary. East European Politics, 36(1), 44-65.

Bernhard, M. (2015). Chronic instability and the limits of path dependence. Perspectives on Politics, 13(4), 976-991.

Bernhard, M. (2020). What do we know about civil society and regime change thirty years after 1989? East European Politics, 36(3), 341-362.

Bernhard, M., Hicken, A., Reenock, C. M., \& Lindberg, S. I. (2015). Institutional subsystems and the survival of democracy: Do political and civil society matter? (Working Paper No. 4). Gothenburg: V-Dem.

Bernhard, M., Hicken, A., Reenock, C., \& Lindberg, S. I. (2020). Parties, civil society, and the deterrence of democratic defection. Studies in Comparative International Development, 55(1), 1-26. 
Bermeo, N. (2016). On democratic backsliding. Journal of Democracy, 27(1), 5-19.

Bickerton, C., \& Accetti, C. I. (2017). Populism and technocracy: Opposites or complements? Critical Review of International Social and Political Philosophy, 20(2), 186-206.

Buštíková, L., \& Baboš, P. (2020). Best in Covid: Populists in the Time of Pandemic. Politics and Governance, 8(4), 496-508.

Buštíková, L. (2019). Extreme reactions: Radical right mobilization in Eastern Europe. Cambridge: Cambridge University Press.

Buštíková, L., \& Guasti, P. (2017). The illiberal turn or swerve in Central Europe?. Politics and Governance, 5(4), 166-176.

Buštíková, L., \& Guasti, P. (2019). The state as a firm: Understanding the autocratic roots of technocratic populism. East European Politics and Societies, 33(2), 302-330.

Caiani, M., \& Graziano, P. (2019). Understanding varieties of populism in times of crises. West European Politics, 42(6), 1141-1158.

Caramani, D. (2017). Will vs. reason: The populist and technocratic forms of political representation and their critique to party government. American Political Science Review, 111(1), 54-67.

Castaldo, A., \& Verzichelli, L. (2020). Technocratic populism in Italy after Berlusconi: The trendsetter and his disciples. Politics and Governance, 8(4), 485-495.

Chaloupkova, M. (2020, May 20). Bylo všeobecně žádoucí, aby to byla Mafra.' České dráhy utratily za reklamu v médiích Agrofertu 112 milionů. [It was politically desirable for it to be MAFRA'. Czech Railways spend 112 million on advertisement in Agrofert media]. iRozhlas. Retrieved from https://www. irozhlas.cz/zpravy-domov/bylo-vseobecne-zadouciaby-byla-mafra-ceske-drahy-utratily-za-reklamu-vmediich_2005200555_ace

Coppedge, M., Gerring, J., Knutsen, C. H., Lindberg, S. I., Teorell, J., Altman, D., . . Ziblatt, D. (2020) V-Dem country-year dataset v10 [Data set]. https://doi.org/ 10.23696/vdemds20

de la Torre, C. (2013). Latin America's authoritarian drift: Technocratic populism in Ecuador. Journal of Democracy, 24(3), 33-46.

Guasti, P. (2016). Development of citizen participation in Central and Eastern Europe after the EU enlargement and economic crises. Communist and PostCommunist Studies, 49(3), 219-231.

Guasti, P. (2020a). The impact of the Covid-19 pandemic in Central and Eastern Europe: The rise of autocracy and democratic resilience. Democratic Theory, 7(2), 47-60.

Guasti, P. (2020b). Swerving towards deconsolidation? Democratic consolidation and civil society in the Czech Republic. In A. Lorenz \& H. Formánková (Eds.), Czech democracy in crisis (pp. 39-62). London: Palgrave Macmillan.
Guasti, P., Mansfeldová, Z., Myant, M., \& Bönker, F. (2014-2020). Annual SGI Country Report Czech Republic. Gütersloh: Sustainable Governance Indicators. Retrieved from https://www.sgi-network.org/ 2020/Downloads

Havlík, V. (2019). Technocratic populism and political illiberalism in central Europe. Problems of PostCommunism, 66(6), 369-384.

Huber, R. A., \& Schimpf, C. H. (2017). On the distinct effects of left-wing and right-wing populism on democratic quality. Politics and Governance, 5(4), 146-165.

Jirák, J., \& Köpplová, B. (2020). Advantages and problems of a liberal democratic media model. Media and politics in the Czech Republic. In Czech Democracy in Crisis (pp. 157-178). London: Palgrave Macmillan.

Kaltwasser, C. R. (2012). The ambivalence of populism: Threat and corrective for democracy. Democratization, 19(2), 184-208.

Kaltwasser, C. R. (2014). The responses of populism to Dahl's democratic dilemmas. Political Studies, 62(3), 470-487.

Kottova, A. (2020, June 23). Babišova vláda chystá pomoc médiím. ,Záleží na rozpočtu, ted’ nemůžeme rozdávat nic,' říká Zaorálek (Babis government preparing aid for the media. 'It depends on the budget, now we cannot give away anythig' says Zaoralek). iRozhlas. Retrieved from https://www.irozhlas.cz/ kultura/koronavirus-podpora-media-ministerstvokultury-zaoralek-babis-mafra_2006231300_ako

Laclau, E. (2005). On populist reason. London: Verso.

Lindberg, S. I. (2013). Mapping accountability: core concept and subtypes. International review of administrative sciences, 79(2), 202-226.

Lorenz, A., \& Formánková, H. (2020). Czech democracy in crisis. London: Palgrave Macmillan.

Lührmann, A., Marquardt, K. L., \& Mechkova, V. (2017). Constraining governments: New indices of vertical, horizontal, and diagonal accountability (Working Paper No. 46). Gothenburg: V-Dem.

Manin, B. (1997). The principles of representative government. Cambridge: Cambridge University Press.

Mechkova, V., Lührmann, A., \& Lindberg, S. I. (2019). The accountability sequence: From de-jure to de-facto constraints on governments. Studies in Comparative International Development, 54(1), 40-70.

Mudde, C., \& Kaltwasser, C. R. (2014). Populism and political leadership. . In R. A. W. Rhodes \& P. Hart (Eds.), The Oxford handbook of political leadership (pp. 376-388). Oxford: Oxford University Press.

Mudde, C., \& Kaltwasser, C. R. (2018). Studying populism in comparative perspective: Reflections on the contemporary and future research agenda. Comparative Political Studies, 51(13), 1667-1693.

OSCE. (2017). The Czech Republic, parliamentary elections 20-21 October 2017. OSCE/ODIHR election assessment mission final report. Warsaw: OSCE. Retrieved from https://www.osce.org/files/ f/documents/b/b/375073.pdf 
Pastorella, G. (2016). Technocratic governments in Europe: Getting the critique right. Political Studies, 64(4), 948-965.

Perottino, M., \& Guasti, P. (2020). Technocratic populism à la française? The roots and mechanisms of Emmanuel Macron's success. Politics and Governance, 8(4), 545-555.

Pospíšil, I. (2020). Activist constitutional court as utility tool for correcting politics: Structure, composition and case-law. In A. Lorenz \& H. Formánková (Eds.), Czech democracy in crisis (pp. 133-155). London: Palgrave Macmillan.

Rosanvallon, P. (2011). Democratic legitimacy: Impartiality, reflexivity, proximity. Princeton, NJ: Princeton University Press.

Rovensky, J. (2019, April 4). Lidovcům, ČSSD i KSČM mizí členové po tisících [Christian Democrats, Social Democrats and Communists are loosing members by thousands]. Novinky.cz. Retrieved from https://www.novinky.cz/domaci/clanek/lidovcumcssd-i-kscm-mizi-clenove-po-tisicich-40279780

Ruth, S. P. (2018). Populism and the erosion of horizontal accountability in Latin America. Political Studies, 66(2), 356-375.

Ruth-Lovell, S. P., Lührmann, A., \& Grahn, S. (2019). Democracy and populism: Testing a contentious rela- tionship (Working Paper No. 91). Gothenburg: V-Dem. Soukup, J. (2020, September 20). ANO ztrácí, komunisté ani lidovci by se do Sněmovny nedostali. [ANO is weakening, Communists and Christian Democrats would not make it into the Parliament]. Novinky.cz. Retrieved from https://www.novinky.cz/volby/doposlanecke-snemovny/clanek/ano-ztraci-komunisteani-lidovci-by-se-do-snemovny-nedostali-40336883

Taggart, P. (2002). Populism and the pathology of representative politics. In Y. Meny \& Y. Surel (Eds.), Democracies and the populist challenge (pp. 62-80). London: Palgrave Macmillan.

Urbinati, N. (2014). Democracy disfigured. Cambridge, MA: Harvard University Press.

Vachudova, M. A. (2019). From competition to polarization in Central Europe: How populists change party systems and the European Union. Polity, 51(4), 689-706.

Weyland, K. (2020). Populism's threat to democracy: Comparative lessons for the United States. Perspectives on Politics, 18(2), 389-406.

Zulianello, M. (2020). Varieties of populist parties and party systems in Europe: From state-of-the-art to the application of a novel classification scheme to 66 parties in 33 countries. Government and Opposition, 55(2), 327-347.

\section{About the Author}

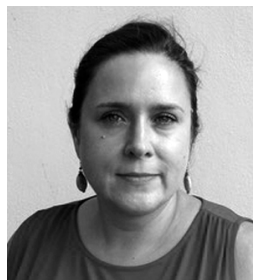

Petra Guasti is a Senior Researcher at the Institute of Sociology of the Czech Academy of Sciences and a Postdoctoral Researcher at the University of Jena. In AY 2018/2019 she was a Democracy Visiting Fellow at the Ash Centre for Democratic Governance and Innovation, Harvard Kennedy School. Her main research focus is the growing tension within the system of representative democracy in respect to its legitimacy. Her research appears in Democratic Theory, Democratization, Communist and Post-Communist Studies, among others. 